\title{
Effects of Partial Mixed Rations on Production, Composition and Nutritional Value of Milk in Lactating Dairy Cows in Temperate Region of Argentina
}

\author{
Gerardo Antonio Gagliostro ${ }^{*}$, Giovanni Alexander Quilaguy-Ayure², \\ Liliana Elisabet Antonacci' ${ }^{1}$, Carlos Alberto Cangiano ${ }^{1}$ \\ ${ }^{1}$ Instituto Nacional de Tecnología Agropecuaria (INTA), Estación Experimental Balcarce, Area de Producción \\ Animal, Balcarce, Argentina \\ ${ }^{2}$ Posgrado en Producción Animal, Unidad Integrada Balcarce, INTA-Facultad de Ciencias Agrarias, Balcarce, Argentina \\ Email: *gagliostro.gerardo@inta.gob.ar
}

How to cite this paper: Gagliostro, G.A., Quilaguy-Ayure, G.A., Antonacci, L.E. and Cangiano, C.A. (2018) Effects of Partial Mixed Rations on Production, Composition and Nutritional Value of Milk in Lactating Dairy Cows in Temperate Region of Argentina. Agricultural Sciences, 9, 852-872. https://doi.org/10.4236/as.2018.97059

Received: June 28, 2018

Accepted: July 27, 2018

Published: July 30, 2018

Copyright $\odot 2018$ by authors and Scientific Research Publishing Inc. This work is licensed under the Creative Commons Attribution International License (CC BY 4.0).

http://creativecommons.org/licenses/by/4.0/

\section{Open Access}

\begin{abstract}
The aim of the study was to determine the effect of supplementing an oat winter pasture with a total mixed ration (TMR) on lactation performance of dairy cows. Nine multiparous Holstein cows were used in a $3 \times 3$ Latin square design with three TMR: pasture ratios at 79:21 (T1), 58:42 (T2) and 33:67 (T3) on a dry matter (DM) basis. The response to the 100\% TMR diet (TMR-100) was tested using an extra period of 14 days inmediately after finishing the Latin square schedule using the nine experimental cows. Total DM intake resulted higher in TMR-100 (28.2 (kg/cow.day) and decreased by 2.64 $\mathrm{kg} /$ cow.day in T1, $5.02 \mathrm{~kg}$ in T2 and $6.68 \mathrm{~kg}$ in T3. Yields of milk $(31.2$ $\mathrm{kg} /$ cow.day) and fat corrected milk $(26.8 \mathrm{~kg} / \mathrm{cow} \cdot$ day $)$ was similar between $\mathrm{T} 1$, T2 and T3. Milk yield resulted higher in TMR-100 (32.1 kg/cow.day) compared to T2 (30.7 kg/cow.day). Milk fat concentration (g/100 g) was higher in T2 (3.13) and T3 (3.20) compared to T1 (2.96) and TMR-100 (2.85) and milk fat yield did not differ. Milk protein content resulted higher in TMR-100 and T2 averaging $3.37 \mathrm{~g} / 100 \mathrm{~g}$ compared to T1 $(3.32 \mathrm{~g} / 100 \mathrm{~g})$. The lowest milk protein concentration was observed in T3 $(3.29 \mathrm{~g} / 100 \mathrm{~g})$ that resulted only different to T2. Milk protein yield did not differ between T1, T2 and T3 averaging $1.03 \mathrm{~kg} / \mathrm{cow} \cdot$ day. A lower protein yield was detected in T2 (1.03) and T3 (1.00) when compared to TMR-100 (1.07). Efficiency of milk production ( $\mathrm{kg}$ milk/kg DM intake) resulted higher in T3 (1.42) compared to T1 (1.25). Treatments that included pasture yielded a higher efficiency of milk production when compared to TMR-100 (1.13). Plasma urea concentration resulted lower in TMR-100 (33.8 $\mathrm{mg} / \mathrm{dl})$ with no significant differences for
\end{abstract}


this parameter between the other treatments. Glucose plasma levels did not differ between T1, T2 and T3 but plasma non-esterified fatty acids (NEFA) gradually increased as the proportion of pasture was enhanced according to the lower energy intake. Plasma insulin levels were higher in TMR-100 and T2 whereas concentration of somatomedins (IGF-1) remained unaffected. Grouth hormone $(\mathrm{GH})$ levels and the $\mathrm{GH} /$ insulin ratio were highly variable and not affected by treatments. Concentration of vaccenic and conjugated linoleic acids gradually increased with the inclusion of pasture in the diet. Supplementing a winter oat pasture with TMR may be a suitable strategy to maintain milk production with a high conversion efficiency but part of the produced milk could be sustained at the expense of endogenous energy mobilization. The conditions of replacing pasture for TMR in high yielding dairy cows should be defined taking into account the depressing effect of pasture on total DM and energy intake when fresh forage is included in high proportion in the diet.

\section{Keywords}

Lactating Dairy Cows, Milk Production, Pasture, Total Mixed Rations

\section{Introduction}

In Argentina as in other countries, there is a tendency to decrease the number of dairy farms while increasing the number of cows within farm and their genetic merit for milk production. This animal concentration would be explained by competition and utilization of agricultural land coupled to the resulting increase in land value. In fact, milk production systems in Argentina are moving towards more intensified farms to release land for the cultivation of soy (Glycine max) which is considered a more profitable activity than milk production [1].

With this scope, many farmers have to decide whether to reduce or even to leave the livestock enterprise resulting in mixed livestock-agriculture, full agriculture systems or the implementation of practices that may increase production and efficiency in the use of land. In this context, experimental information on milk production comparing partial or total confinement feeding systems as an alternative to grazing based systems is still scarce.

Grazing systems are characterized by a lower environmental impact [2] and a lower production cost [3] but present nutritional limitations that prevent the expression of the milk production potential of high yielding dairy cows. The low energy and DM contents of pastures coupled to the high fiber concentration and intake are factors potentially limiting DM and energy intakes of high yielding dairy cows [1] [4] [5] [6] [7]. These pasture properties may negatively affect milk production enhancing losses of body weight (BW) and body condition score (BCS) in high yielding dairy cows [1] [4]-[9].

To mitigate these negative effects, a widely used practice is the supplementation 
with energy concentrates although the productivity can be lower than with the use of combinations of pasture and TMR or confined diets [7]. In turn, the low growth-rate of temperate pastures in autumn-winter leads to the use of conserved forages as corn silage alone. An option may be theuse of conserved forages with energy and protein concentrates, minerals and vitamins in a balanced way as TMR diets to sustain the cow requirements for high milk production. This feeding strategy would allow the expression of the milk production potential of high yielding dairy cows [10] but feeding cost are higher than pasture-feeding representing more than $50 \%$ of the total costs [11].

An interesting alternative is the combination of TMR and grazing which is known as a partially mixed ration (PMR) since pasture is directly grazed by the cows and hence not physically included in the TMR. It combines partial advantages of each system and pasture would not only reduce the amount of TMR included in the total diet and feeding cost but may also improve the dairy herd health [2]. In effect, PMR diets showed to increase milk production [9] [12] [13] reducing feed costs [3] and environmental impacts [2] while improving the healthy value of milk fat by higher concentrations of linolenic, vaccenic and conjugated linoleic acids [13] [14] [15].

Most of the published studies compared TMR systems vs some combination of pastures plus concentrate or pasture plus TMR. Such comparisons included TMR vs pasture [4] [16], TMR vs pasture plus concentrate [3] [9], TMR vs pasture during the morning or afternoon plus TMR [5] and TMR vs pasture plus concentrate vs a combination of pasture with TMR [7].

The results showed that TMR diets increased total dry matter (DM) intake [3] [4] [5] [7], milk production [3] [4] [5] [7] [9], body weight [5] [9] [10] and body condition score [5] [6] [10] [11].

There is still scarce information on the production response obtained in feeding systems combining different proportions of TMR and pasture [12] [15] [17]. Ina 8 week-long experiments conducted in autumn and spring it was suggested that the autumn pasture can be included in up to $41 \%$ of the total PMR without affecting the productive response compared to a TMR system [12]. In addition no differences in milk production were observed between cows fed $100 \%$ TMR or a TMR-Pasture ratio of 79:21 or 63:37 [7]. This result would be explained by an adequate energy intake in all treatments according to production level [15]. The maximum level of pasture inclusion in the total ration without causing losses in the productive response requires further investigation.

The aim of this experiment was to determine the effect of TMR replacement by pasture on DM and energy intake, milk production and composition, plasma metabolite and hormone concentrations and milk FA profile.

\section{Materials and Methods}

\subsection{Treatments, Animals and Experimental Design}

The experiment was carried out at the National Institute of Agricultural Technology 
(INTA) at the Balcarce Agricultural Experimental Station $\left(37^{\circ} 45^{\prime} \mathrm{S}, 58^{\circ} 18^{\prime} \mathrm{W}, 130\right.$ $m$ asl) from the months of May to July (autumn-winter time). The trial started with 12 multiparous autumn-calving Holstein cows averaging $603( \pm 51) \mathrm{kg} \mathrm{BW}$, producing $28.8( \pm 6.4) \mathrm{kg}$ milk/day and $52( \pm 20)$ days in milk.

The experimental design was a triple Latin square with 4 treatments and 4 experimental periods with 16 days of adaptation and 5 for measurements. Before the start of the trial, all cows were fed a $100 \%$ TMR diet during 14 days to estimate maximal DM intake and calculate the quantity of pasture and TMR to provide according to pre-planned treatments. Owing to health problems three cows had to be removed and the experiment should have been reduced to a Latin square with 9 cows, 3 treatments and 3 experimental periods. Treatments were three combinations of TMR and pasture at (DM basis) 79:21 (T1), 58:42 (T2) and 33:67 (T3) as PMR. Production response to feeding a TMR-100\% diet, was evaluated including an extra period of 14 days immediately after finishing the Latin square schedule with the 9 cows.

The TMR composition was calculated using the INTA-Racion program assuming an average cow of $600 \mathrm{~kg}$ BW producing $40 \mathrm{~kg}$ of milk with $34 \mathrm{~g} / \mathrm{kg}$ milk fat and $115 \mathrm{~g} / \mathrm{kg}$ of total solids. No BW losses were assumed and energy requirements were increased in $10 \%$ for voluntary activity of grazing. On a DM basis, the TMR was composed by corn silage (35.9\%), pelletized soybean meal $(6.5 \%)$, cracked soybean $(6.4 \%)$, a commercial concentrate $(49.2 \%)$ and hydrolyzed feather meal $(2.0 \%)$. In turn, the commercial concentrate was composed of $68 \%$ corn grain, $22 \%$ soybean meal, $8 \%$ wheat bran and a vitamin-mineral core including monensin.

The DM content of the TMR offered and refused was daily determined. The feeders were located in individuals pens and cleaned up prior to the entry of the animals to remove feed refusals to calculate DM intake by quantities offered and refused. The TMR was prepared daily using a horizontal mixer equipment (Mainero, Model 2910), weighed and delivered to each cow according to the correspondent treatment. After the morning milking, cows were fed the TMR with fresh water avalilable ad libitum. In TMR-100, the ration was offered three times a day at $08.00(40 \%), 10: 30(40 \%)$ and $16.00 \mathrm{~h}(20 \%)$. In T1 and T2 the TMR was distributed at $08.00 \mathrm{~h}(53 \%)$ and $10: 30 \mathrm{~h}(47 \%)$ (T1) and $80 \%$ and $20 \%$ (T2). Finally, in T3 the TMR was distributed in a single meal at $08.00 \mathrm{~h}$. Once cows consumed the fixed daily amount of TMR they were conducted to the grazing strips at 10:30, 16:30 and 18:30 hours in T3, T2 and T1 respectively.

Pasture utilization was fixed at $60 \%$ and herbage allowance (kg DM/cow.day) was calculated using the following equations: $\mathrm{T} 1=$ potential intake of TMR $\times$ $0.25 / 0.60 ; \mathrm{T} 2=$ potential intake of TMR $\times 0.50 / 0.60$ and $\mathrm{T} 3=$ potential intake of TMR $\times 0.75 / 0.60$. The grazing area was defined weekly from estimated forage biomass using a pasture-meter by linear regression equations between height and the available biomass. During the last three days of each experimental period cows grazed on individual plots to estimate pasture DM intake by the 
difference method between the initial and final biomass. Average pasture intake of the three consecutive days of each experimental period were used for statistical analysis.

\subsection{Sampling Measurements and Laboratory Procedures}

During intake measurements, pasture was hand-plucked in the grazing horizon to obtain one poole pasture sample per period. Forage was dry-oven at $60^{\circ} \mathrm{C}$, milled $(1 \mathrm{~mm})$ and analyzed for organic matter $(\mathrm{OM})$ crude protein $(\mathrm{CP})$, soluble carbohydrates (SCA), neutral detergent fiber (NDF), acid detergent fiber (ADF), ether extract (EE), apparent in vitro dry matter digestibility at $48 \mathrm{~h}$ (IVDMD) and starch by methods described in [18].

Cows were milked twice daily at 6:00 and 16:00 hours and individually milk production was daily recorded throughout the trial. The average values of the last five days of each experimental period were computed for statiscal analysis. Milk fat, protein and lactose content was determined by infrared spectrophotometry (Milko Scan 300, Foss Electric, DK) according to [19] on samples taken over the last four days of each period. Samples of milk were also analyzed for FA composition by gas-liquid chromatography (GLC) as previously described [18]. Briefly, fat was extracted from raw milk with a warm detergent Triton solution that was a mixture of $12 \mathrm{ml}$ of Triton X-100, $50 \mathrm{ml}$ of isopropylic alcohol, $2.5 \mathrm{~g}$ of urea, $25 \mathrm{~g}$ of sodium hexametaphosphate and distilled water. The extraction was done in an oven at $90^{\circ} \mathrm{C}$. The hydrophobic upper layer was separated from the aqueous layer and transferred into a vial. For the esterification and methylation of FA, methyl esters were obtained from milk fat by adding $5 \mathrm{ml}$ of hexane, mixing in vortex. It was added $0.2 \mathrm{ml}$ of esterificant reactives, mixed in vortex for 1 minute, leaving in the vial for 5 minutes. Latter on added $0.5 \mathrm{~g}$ of sodium sulfate acid monohydrate and mixed using a vortex and centrifuged ( $3 \mathrm{~min}$ at $2500 \mathrm{rpm}$ ). The supernatant was transferred to a glass vial and injected in a gas-liquid chromatograph (GLC). Chromatography was performed using a pillary column (Varian WCOT-100M, $100 \mathrm{~m} \times 0.25 \mathrm{~mm} \times 0.25 \mu \mathrm{m}$ ) in an Agilent 6890 series plus. One $\mu \mathrm{l}$ of each sample was injected. The initial oven temperature was held at $70^{\circ} \mathrm{C}$ for 1 minute, increased $5^{\circ} \mathrm{C} / \mathrm{min}$ to $100^{\circ} \mathrm{C}$, then, increased $10^{\circ} \mathrm{C} / \mathrm{min}$ to $160^{\circ} \mathrm{C}$, increased $5^{\circ} \mathrm{C} / \mathrm{min}$ to $175^{\circ} \mathrm{C}$, and increased $5^{\circ} \mathrm{C} / \mathrm{min}$ to final temperature of $225^{\circ} \mathrm{C}$. Hidrogen was the gas carrier, the flow was held at $1.4 \mathrm{~mL} / \mathrm{min}$. The injector temperature was $250^{\circ} \mathrm{C}$ and the FID detector temperature was maintained at $355^{\circ} \mathrm{C}$. Individual isomers (cis-9,

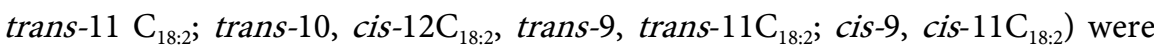
identified based on individual standards (Matreya, Inc. Cathalogues 1255; 1254; 1257 ; 1256), whereas the individual standards of trans- $\mathrm{C}_{18: 1}, \mathrm{C}_{20: 4}, \mathrm{C}_{20: 5}$ and $\mathrm{C}_{22: 6}$ were purchased at Sigma (Cathalogues V1381; A9298; E2012; D2659).

Average values were used to perform statistical analysis. Cows were weighed at the end of each experimental period after the morning milking. Before weighing, blood samples were obtained by jugular venipuncture and collected in 
tubes containing EDTA $(0.342 \mathrm{~mol} / \mathrm{L}, \mathrm{pH}$ 7.2, Wiener Laboratory, Rosario, Argentina), centrifuged $(3000 \times \mathrm{g}$ for $15 \mathrm{~min})$ and plasma was stored at $-24^{\circ} \mathrm{C}$ until analysis using enzimatic kits for glucose (Wiener Laboratory, Rosario, Argentina), urea nitrogen (Wiener Lab., Rosario, Argentina) and non-esterified fatty acids (NEFA, Randox Laboratories Ltd., UK). Plasma concentrations of IGF-1, somatotrophin $(\mathrm{GH})$ and insulin were assayed by radioimmunoassay as described in [20].

\subsection{Statistical Analyses}

Data were analyzed in a model that included treatment as fixed effect and square, period, period $\times$ treatment interaction and cow as random effects using the PROC MIXED of SAS [21]. Differences between the TMR-100 and the other treatments were stated using the Student T-test for pairwise observations.

\section{Results and Discussion}

\subsection{TMR and Pasture Composition}

Dry matter content of corn silage resulted somewhat higher than the average value of $317 \mathrm{~g} / \mathrm{kg}$ reported for Argentine corn silage whereas the NDF content resulted lower than the mean value of $510 \mathrm{~g} / \mathrm{kg}$ [22]. CP content was similar to the average local values [22]. The others constituents of the TMR were within the normal range (Table 1 ).

Chemical composition of the feedstuffs included in the TMR is shown in Table 1.

Pasture DM content averaged $162 \mathrm{~g} / \mathrm{kg}( \pm 3.8)$ comprising $898 \mathrm{~g} \mathrm{OM} / \mathrm{kg}$ $( \pm 3.2)$. The average IVDMD $(795 \pm 10.3 \mathrm{~g} / \mathrm{kg})$ and CP $(218 \pm 5.7 \mathrm{~g} / \mathrm{kg})$ resulted high with a moderate content of SCH $(117 \pm 3.4 \mathrm{~g} / \mathrm{kg}), \mathrm{ADF}(205 \pm 6.1 \mathrm{~g} / \mathrm{kg})$ and $\mathrm{EE}(33 \pm 1.2 \mathrm{~g} / \mathrm{kg})$. These parameters are characteristic in high quality pastures but it should be noted that the pasture DM content was insufficient and could compromise DM intake [16]. The high pasture NDF content $(416 \pm 10 \mathrm{~g} / \mathrm{kg}) \mathrm{can}$ also limit total DM intake as it was observed (Table 2) whith incresed contribution of the oat-pasture in the PMR diets. The result was in agreement with those reported by [5] [12] [13] using autumn-winter pastures.

\subsection{Pasture and TMR Intake}

According to pre-planned design, pasture intake increased from T1 to T3 (Table 2) due to the increased pasture supply, the greatest grazing-periods and the lower TMR offered. Additional factors that may affect pasture intake are the change in the normal grazing-pattern imposed by treatment schedules as well as the inherent difficulty of harvesting the pasture compared to the ease of ingesting TMR diets. In the experiment of [17] the lack of differences in milk production after one or two grazing sessions in a 50:50 Pasture-TMR ration could indicate grazing compensatory mechanisms. 
Table 1. Chemical composition (g/kg MS) of the feedstuffs included in thetotal mixed ration.

\begin{tabular}{ccccccc}
\hline & DM & OM & IVDMD & CP & NDF & EE \\
\hline & $(\mathrm{g} / \mathrm{kg})$ & & & $\mathrm{g} / \mathrm{kg} \mathrm{DM}$ & & \\
\hline Corn silage & 370 & 927 & 685 & 62 & 457 & $\mathrm{nd}$ \\
Soybean meal & 891 & 932 & 881 & 446 & 158 & $\mathrm{nd}$ \\
Whole soybean & 908 & 947 & 875 & 365 & 97 & 168 \\
Concentrate & 907 & 920 & 758 & 193 & 243 & 42 \\
Feather meal & 961 & $\mathrm{nd}$ & $\mathrm{Nd}$ & 797 & $\mathrm{nd}$ & 114 \\
TMR & 596 & 907 & 732 & 186 & 300 & 34 \\
\hline
\end{tabular}

DM: Dry Matter, OM: Organic matter, IVDMD (48 hours), CP: Crude protein, NDF: neutral detergent fiber, EE: Ether extract. Estimated Net Energy of Lactation (NEl) was $1.64 \mathrm{Mcal} / \mathrm{kg}$ DM.

Table 2. Dry matter and nutrient intake in lactating dairy cows fed a total mixed ration alone (TMR-100) or combined with pasture at 79:21 (T1), 58:42 (T2) and 33:67 (T3) ratios.

\begin{tabular}{|c|c|c|c|c|c|c|c|c|c|}
\hline \multirow{3}{*}{ Parameters } & \multicolumn{5}{|c|}{ Treatments } & \multicolumn{4}{|c|}{${ }^{1}$ Effects } \\
\hline & \multirow{2}{*}{ TMR- $100^{2}$} & \multicolumn{3}{|c|}{ Latin Square $^{3}$} & \multirow{2}{*}{$\mathrm{SEM}^{4}$} & \multirow{2}{*}{$\mathrm{T}$} & \multirow{2}{*}{ S } & \multirow{2}{*}{$\mathrm{P}$} & \multirow{2}{*}{$\mathrm{P}^{*} \mathrm{~T}$} \\
\hline & & $\mathrm{T} 1$ & $\mathrm{~T} 2$ & $\mathrm{~T} 3$ & & & & & \\
\hline \multicolumn{10}{|l|}{$\begin{array}{l}\text { DM intake, } \\
\mathrm{kg} / \text { cow } \cdot \text { day }\end{array}$} \\
\hline Pasture & $-\cdots$ & $5.3^{c}$ & $9.8^{\mathrm{b}}$ & $14.5^{\mathrm{a}}$ & 0.36 & $<0.01$ & 0.08 & 0.02 & 0.08 \\
\hline TMR & 28.2 & $20.3^{\mathrm{a} \star *}$ & $13.4^{\mathrm{b} \star *}$ & $7.1 c^{\star *}$ & 0.33 & $<0.01$ & 0.07 & $<0.01$ & 0.01 \\
\hline Total & 28.2 & $25.6^{\mathrm{a} \star}$ & $23.2^{\mathrm{b} * *}$ & $21.6^{c * *}$ & 0.44 & $<0.01$ & 0.02 & $<0.01$ & $<0.01$ \\
\hline Total intake \% BW & 4.42 & $4.23^{\mathrm{a}}$ & $3.84^{\mathrm{b} * *}$ & $3.57^{b * *}$ & 0.12 & $<0.01$ & 0.29 & $<0.01$ & 0.08 \\
\hline \multicolumn{10}{|l|}{ ME Intake ${ }^{5}$} \\
\hline \multicolumn{10}{|l|}{$\mathrm{Mcal} /$ cow.day } \\
\hline Pasture ME & $-\cdots$ & $15.1^{\mathrm{c}}$ & $28.0^{\mathrm{b}}$ & $41.6^{\mathrm{a}}$ & 1.02 & $<.001$ & 0.07 & 0.11 & 0.06 \\
\hline TMR ME & 73.6 & $53.0^{\mathrm{a} \star \star}$ & $35.1^{\mathrm{b} * *}$ & $18.4^{c * *}$ & 0.86 & $<.001$ & 0.07 & $<0.01$ & 0.01 \\
\hline Total ME & 73.6 & $68.0^{\mathrm{a} \wedge}$ & $63.1^{\mathrm{b} * *}$ & $60.0^{\mathrm{b} * *}$ & 1.20 & $<.001$ & 0.02 & $<0.01$ & $<0.01$ \\
\hline \multicolumn{10}{|l|}{$\begin{array}{l}\text { CP Intake } \\
\mathrm{kg} / \text { cow } \cdot \text { day }\end{array}$} \\
\hline Pasture CP & $\cdots$ & $1.14^{\mathrm{c}}$ & $2.11^{\mathrm{b}}$ & $3.17^{\mathrm{a}}$ & 0.08 & $<0.01$ & 0.07 & $<0.01$ & 0.01 \\
\hline TMR CP & 4.9 & $2.64^{\mathrm{a} \star *}$ & $1.69^{b * *}$ & $0.91^{c * *}$ & 0.05 & $<0.01$ & 0.09 & $<0.01$ & $<0.01$ \\
\hline Total CP & 4.9 & $3.78^{b \star *}$ & $3.80^{\mathrm{b} * \star}$ & $4.09^{a \star \star}$ & 0.09 & 0.05 & 0.03 & $<0.01$ & 0.01 \\
\hline \multicolumn{10}{|l|}{ NDF Intake ${ }^{6}$} \\
\hline \multicolumn{10}{|l|}{$\mathrm{kg} /$ cow $\cdot$ day } \\
\hline PastureNDF & -- & $2.20^{\mathrm{a}}$ & $4.79^{\mathrm{b}}$ & $6.05^{c}$ & 0.12 & $<0.01$ & 0.07 & $<0.01$ & 0.02 \\
\hline TMR NDF & 8.2 & $6.86^{c * *}$ & $4.08^{\mathrm{b} * *}$ & $2.52^{\mathrm{a} \star *}$ & 0.15 & $<0.01$ & 0.09 & $<0.01$ & 0.07 \\
\hline Total NDF & 8.2 & $9.06^{\mathrm{a} *}$ & $8.88^{\mathrm{b}}$ & $8.57^{\mathrm{b}}$ & 0.18 & 0.01 & 0.02 & $<0.01$ & 0.01 \\
\hline
\end{tabular}


Continued

$\mathrm{NE}_{1}$ Intake $_{1}^{7}$

$\mathrm{Mcal} /$ cow·day

$\begin{array}{cccccccccc}\text { Pasture } \mathrm{NE}_{1} & \cdots & 9.6^{\mathrm{c}} & 17.9^{\mathrm{b}} & 26.6^{\mathrm{a}} & 0.65 & <0.01 & 0.07 & 0.18 & 0.05 \\ \text { TMR NE }_{1} & 45.5 & 32.7^{\mathrm{a} \star \star} & 21.7^{\mathrm{b} * \star} & 11.4^{\text {c**}} & 0.53 & <0.01 & 0.07 & <0.01 & 0.01 \\ & & & & & & & & & \\ \text { Total NE } & 45.5 & 42.4^{\mathrm{a}} & 39.6^{\mathrm{b} * \star} & 38.0^{\mathrm{b} * \star} & 0.75 & <0.01 & 0.02 & <0.01 & <0.01\end{array}$

${ }^{\mathrm{a}, \mathrm{b}, \mathrm{c}} \mathrm{In}$ the same row different letters indicate significant differences between T1, T2 and T3 (LSD, $\alpha=0.05$ ). $\wedge P<0.10,{ }^{\star} P<0.05,{ }^{*} P<0.01: P$-value of the Student's $\mathrm{t}$ statistic for paired observations (comparison with treatment TMR-100). ${ }^{1}$ Effects: $\mathrm{T}=$ Treatment, $\mathrm{P}=$ Period; $\mathrm{S}=$ Square. ${ }^{2}$ Average of nine cows during the additional period. ${ }^{3}$ Least squares means. ${ }^{4}$ Standard error of the least squares means. ${ }^{5}$ Estimated from digestibility values $\left(3608\right.$ * IVDMS). ${ }^{6}$ Protein and FDN intakes were calculated from composition analysis. ${ }^{7} \mathrm{Net}$ Energy of lactation $\left(\mathrm{NE}_{\mathrm{L}}\right)$ for TMR (1.61 Mcal/kg DM); Pasture (1.84 Mcal/kg DM). Calculated using the formula EM $\times[0.08368 \times(\mathrm{EM})+0.4]$, (Feeding Standards for Australian Livestock (Ruminants, CSIRO, $1990[19])$.

A high total DM intake was observed in TMR-100 (28.2 kg DM/cow.day) representing $4.42 \%$ of BW resulting $10 \%, 23 \%$ and $31 \%$ higher than values for T1, T2 and T3 and also than those reported in [5] (26.6 kg), [7] (26.7 kg), [15] $(22.7 \mathrm{~kg})$ and [12] $(25.8 \mathrm{~kg})$. In [12] the NDF content of the TMR $(430 \mathrm{~g} / \mathrm{kg} \mathrm{DM})$ was greater than observed in the present trial $(291 \mathrm{~g} / \mathrm{kg} \mathrm{DM})$ that may explain in part the higher total DM intake (Table 2). In their fall-time experiment [12] reported a DM intake equivalent to $4.46 \% \mathrm{BW}$ when cows were fed the TMR-100\% a value that was near to the $4.42 \%$ observed (Table 2). DM intake in T1 $(4.23 \%$ $\mathrm{BW}$, Table 2) resulted higher than the $3.78 \% \mathrm{BW}$ reported by [12] but close to the 4.5\% BW reported in [23] using a 73:27 TMR-pasture ratio when cows were offered $30 \mathrm{~kg} \mathrm{DM} /$ cow.day of pasture. In the 59:41 treatment of [12] close to T2 of the present experiment, DM intake averaged $3.86 \% \mathrm{BW}$ resulting similar to the $3.84 \%$ observed here (Table 2). In our trial and in experiments of [12] and [13] maximum DM intake in autumn-winter experiments was obtained in TMR-100 and decreased with the increase of pasture participation in the PMR. Total DM intake in the PMR's (Table 2) resulted consistent with [12] and ranged from 25.6 $\mathrm{kg} \mathrm{DM} /$ cow.day in T1 (79:21) to $21.6 \mathrm{~kg}$ in T3 (33:67). No significant differences in total DM intake between TMR-100 (22.7 kg DM/cow.day) or when the TMR/pasture ratios were 79:21 (23.26 kg DM) and 63:27 (22.99 kg DM) were detected by [15]. In a similar experiment, a linear increase in total DM intake was reported when the level of TMR was enhanced [13].

The higher total DM intake resulted in higher energy consumption in TMR-100 and in T1 (79:21) compared to treatments with a greater inclusion of pasture that in turn did not differ between them (Table 2). The higher total DM intake in TMR-100 resulted in maximum intake of protein, followed by T3 with lower values for T1 and T2 (Table 2). Intake of CP gradually increased with the amount of pasture consumed (Table 2) a result consistent with the increased circulating levels of plasma urea observed (Table 3) that were negatively correlated $(\mathrm{r}=-0.42, P<0.01)$ to BW gain. 
Table 3. Milk production and composition in lactating dairy cows fed a total mixed ration alone (TMR-100) or combined with pasture at 79:21 (T1), 58:42 (T2) and 33:67 (T3) ratios.

\begin{tabular}{|c|c|c|c|c|c|c|c|c|c|}
\hline \multirow{3}{*}{ Parameters } & \multirow{3}{*}{ TMR- $100^{2}$} & \multicolumn{4}{|c|}{ Treatments } & \multicolumn{4}{|c|}{${ }^{1}$ Effects } \\
\hline & & \multicolumn{3}{|c|}{ Latin Square ${ }^{3}$} & \multirow{2}{*}{$\mathrm{EEM}^{4}$} & \multirow{2}{*}{$\mathrm{T}$} & \multirow[b]{2}{*}{$S$} & \multirow[b]{2}{*}{$\mathrm{P}$} & \multirow{2}{*}{$\mathrm{P}^{*} \mathrm{~T}$} \\
\hline & & $\mathrm{T} 1$ & $\mathrm{~T} 2$ & $\mathrm{~T} 3$ & & & & & \\
\hline Milk, kg/cow.day & 32.1 & 32.2 & $30.7^{*}$ & 30.6 & 1.63 & 0.35 & 0.13 & 0.69 & 0.52 \\
\hline FCM $4 \%^{5}$, g/cow.day & 26.5 & 27.0 & 26.6 & 26.7 & 1.46 & 0.91 & 0.24 & 0.28 & 0.75 \\
\hline \multicolumn{10}{|l|}{ Milk fat } \\
\hline$g / 100 \mathrm{~g}$ & 2.85 & $2.96^{\mathrm{b}}$ & $3.13^{\text {a* }}$ & $3.20^{\mathrm{a} * *}$ & 0.13 & 0.01 & 0.45 & 0.02 & 0.49 \\
\hline $\mathrm{kg} /$ cow.day & 0.91 & 0.94 & 0.95 & 0.97 & 0.06 & 0.85 & 0.47 & 0.11 & 0.81 \\
\hline \multicolumn{10}{|l|}{ Protein } \\
\hline$g / 100 \mathrm{~g}$ & 3.37 & $3.32^{\mathrm{ab} *}$ & $3.37^{\mathrm{a}}$ & $3.29^{\mathrm{b}}$ & 0.06 & 0.06 & 0.82 & $<0.01$ & 0.02 \\
\hline $\mathrm{kg} /$ cow $\cdot$ day & 1.07 & 1.06 & $1.03^{*}$ & $1.00^{*}$ & 0.06 & 0.29 & 0.18 & 0.28 & 0.90 \\
\hline Lactose, $\mathrm{g} / 100 \mathrm{~g}$ & 4.89 & 4.82 & $4.70^{\star *}$ & $4.74^{* *}$ & 0.09 & 0.24 & 0.31 & 0.75 & 0.56 \\
\hline $\begin{array}{c}\text { Efficiency, } \\
\text { kg milk/kg DM }\end{array}$ & 1.13 & $1.25^{\mathrm{b} \wedge}$ & $1.33^{\mathrm{ab} \star \star}$ & $1.42^{\mathrm{a} * *}$ & 0.08 & 0.09 & 0.45 & 0.04 & 0.73 \\
\hline
\end{tabular}

${ }^{\mathrm{a}, \mathrm{b}, \mathrm{c}} \mathrm{Different}$ letters in the same row indicate significant differences between treatments T1, T2 and T3 (LSD, $\alpha=0.05) . \wedge: P<0.10,{ }^{*}: P<0.05,{ }^{* *}: P<0.01$ ( $P$-value of the Student's $\mathrm{t}$ Test for paired observations (comparison with treatment TMR-100). ${ }^{1}$ Effects: $\mathrm{T}=$ Treatment, $\mathrm{P}=$ Period, $\mathrm{S}=$ Square. ${ }^{2}$ Average. ${ }^{3}$ Least squares means. ${ }^{4}$ Standard error of least squares means. ${ }^{5} 4 \%$ Fat corrected milk.

The concentration of NDF was minimal in TMR-100 (291 g/kg DM) and increased with pasture intake in T1 $(354 \mathrm{~g} / \mathrm{kg} \mathrm{DM}), \mathrm{T} 2(383 \mathrm{~g} / \mathrm{kg} \mathrm{DM}$ and T3 (397 g/kg DM). While the concentration of NDF of corn silage $(457 \mathrm{~g} / \mathrm{kg} \mathrm{DM}$, Table 1) was higher than the pasture ( $416 \mathrm{~g} / \mathrm{kg} \mathrm{DM})$ the higher DM intake with greater participation of TMR in the total ration could be explained by a high rate of passage of corn silage when it is chopped to a small particle size. The estimation of the effective fiber content in corn silage indicated that $7 \%$ of the particles were retained on the top rack of the sieves a value that is considered compatible with a proper supply of effective fiber. In fact, no differences in ruminal degradability of silage DM or NDF were detected [24].

Taken together, the results suggested a depressive effect of pasture on total DM and energy intakes when it is included as part of the PMR even though pasture offered was $67 \%$ higher than the expected pasture intake. Qualitative deficiencies of forage like DM, NDF and energy content added to animal behavior factors (access time to pasture, grazing pattern) may help to explain in part the results and are predisposing to induce BW losses and body condition in cows of high genetic merit for milk production.

\subsection{Milk Production and Composition}

Yields of milk and fat corrected milk resulted similar between the PMR diets 
(Table 3).When cows were fed the TRM-100 diet, a lower average milk production $(-1.4 \mathrm{~kg} / \mathrm{cow} \cdot$ day) was observed only when compared to $\mathrm{T} 2$. In the companion experiment of [13] linear increases were found in milk protein and fat yields when TMR replaced the oat pasture. In that experiment [13] the higher yields were observed in TMR-100 and TMR-75 compared to TMR-50 and TMR-25.

The higher milk production in TMR-100 (Table 3) was also reported by [5] and [7] and in the spring experiment of [12]. This last author [12] reported a linear decrease in milk production from $36.6 \mathrm{~kg} / \mathrm{cow} \cdot$ day in TMR-100 to $32.7 \mathrm{~kg}$ when pasture represented $35 \%$ of the PMR. The combination of a grazing period of 7 to $14 \mathrm{~h}$ and TMR produced less milk and milk protein yield than TMR-100 with no differences in milk fat output or milk protein content [17].

Despite the higher DM intake (Table 2) and the positive correlation between DM intake and milk production $(\mathrm{r}=0.49, P<0.01)$ or the lower energy expenditure associated to grazing activity in treatments with lower pasture, a net effect on milk production when pasture was replaced by TMR was not observed as reported in other experiments [7] [12] [15]. In the autumn experiment of [12] despite the low DM content (16.4\%) of the pasture and its CP excess (23.7\%), no differences in milk production were detected when TMR ranged between $100 \%$ and 59\% of the PMR. In the experiment of [5] cows fed the TMR-100 produced more milk $(1-2 \mathrm{~kg}, P<0.05)$ than cows fed combinations of pasture and TMR with no differences in fat corrected milk. In [15] no differences were reported in milk production (34.6 kg milk/cow.day) from cows fed TMR + concentrate or when TMR + concentrate were combined to pasture at 79:21 (35.4 kg/cow·day) or $63: 27$ ratios $(33.6 \mathrm{~kg} / \mathrm{cow} \cdot$ day). The variability in milk response would be explained by factors like DM intake, nutrtitional quality of TMR components, type and quality of pasture grazed and increased maintenance requirements generated by the activities of walking and grazing [12].

There are few studies reporting DM intake and milk production with different proportions of grazed pasture and TMR. In an attempt to synthesize the available data, it was found that both, intake and milk production, increased as the proportion of TMR in the diet was enhanced. In the case of DM intake, it was detected an increase of about $0.07 \mathrm{kgDM} / \mathrm{cow} \cdot$ day for every $10 \%$ increase in the intake of TMR (Figure 1) indicating a clear addition effect that equated to what happens with the traditional supplementation based on concentrates. At zero supplement intake (equivalent to $100 \%$ pasture), the estimated intake was more than $18 \mathrm{~kg} \mathrm{DM} /$ cow.day (Figure 1). Milk yield was increased by $0.8 \mathrm{~kg} / \mathrm{cow} \cdot$ day every $10 \%$ of additional intake of TMR (Figure 2). Cows eating $100 \%$ pasture or TMR-100 would have an estimated average milk production of 25.5 and 33.5 $\mathrm{kg} /$ day respectively for the production range (20 - $40 \mathrm{~kg} /$ day) explored in Figure 2. Similar results were computed in the companion trial of [13].

In a $100 \%$ pasture diet, early lactation Holstein cows consumed only 17 $\mathrm{kg} /$ cow day equivalent to $3.3 \% \mathrm{BW}$ resulting lower than the $24 \mathrm{~kg} / \mathrm{cow} \cdot$ day $(4.1 \%$ 
BW) observed in the $100 \%$ TMR diet [24]. These results were comparable to trends presented in Figure 1. When the authors analyzed milk production over the full lactation, a daily milk production of $20 \mathrm{~kg} /$ cow in $100 \%$ pasture and 34 $\mathrm{kg} / \mathrm{cow}$ in TMR-100 were observed [25].

Milk production obtained when feeding the TMR-100 diets showed a high variability of response as shown in Figure 2 and [13]. This result can be explained by the type and quality of farm facilities that influence the optimal animal welfare which in turn impacts on productivity and also by the chemical composition and nutritonal value of feedstufss and TMR's between trials that are also higly variable. In short term experiments, a transient energy deficit may also be temporarily offset by mobilization of body reserves to sustain milk production. Consistent with this hypothesis, plasma NEFA levels increased in cows from treatments with higher amounts of pasture (Table 4) a resultthat was also observed in [13].

In our trial, milk fat concentration resulted highest in treatments with greater participation of pasture ( $42 \%$ and $67 \%$ ). The result was consistent with the highest ruminal acetate/propionate ratio observed in the companion experiment using fistulated cows [24] as well as with levels of circulating NEFA (Table 4) that may help to maintain milk fat content and mammary lipid secretion explaining in part the higher milk fat concentration observed in T2 (58:42) and T3 (33:67). Several experiments showed that the effects on milk fat content is somewhat equivocal [5] [7] [12] [13] [15]. The decline in milk fat content observed in

Table 4. Plasma metabolite and hormone concentrations in dairy cows fed only a completely mixed ration (TMR-100) or combinations of TMR and pasture at 79:21 (T1), 58:42 (T2) and 33:67 (T3).

\begin{tabular}{|c|c|c|c|c|c|c|c|c|c|}
\hline & \multicolumn{5}{|c|}{ Treatments } & \multicolumn{4}{|c|}{${ }^{1}$ Effects } \\
\hline \multirow[b]{2}{*}{ Parameters } & \multirow{2}{*}{ TMR- $100^{2}$} & \multicolumn{3}{|c|}{ Latin square $^{3}$} & \multirow{2}{*}{- SEM $^{4}$} & \multirow{2}{*}{$\mathrm{T}$} & \multirow[b]{2}{*}{$\mathrm{S}$} & \multirow[b]{2}{*}{$\mathrm{P}$} & \multirow[b]{2}{*}{$\mathrm{P}^{*} \mathrm{~T}$} \\
\hline & & $\mathrm{T} 1$ & $\mathrm{~T} 2$ & $\mathrm{~T} 3$ & & & & & \\
\hline Urea, mg/dl & 33.8 & $40.6^{*}$ & $39.4^{*}$ & $42.5^{\star \star}$ & 2.1 & 0.42 & 0.77 & 0.09 & 0.23 \\
\hline Glucose, mg/dl & 81.76 & 88.9 & $95.4^{*}$ & 80.6 & 4.8 & 0.13 & 0.53 & 0.12 & 0.80 \\
\hline $\mathrm{NEFA}^{5}, \mathrm{meq} / \mathrm{l}$ & 150.9 & $198.9^{\mathrm{b}}$ & $253.9^{\mathrm{ab} \wedge}$ & $326.8^{\mathrm{a} *}$ & 39.5 & 0.06 & 0.95 & 0.00 & 0.13 \\
\hline $\begin{array}{l}\text { Somatomedins } \\
\text { (IGF-1), ng/ml }\end{array}$ & 134.8 & 170.7 & 106.9 & 130.3 & 33.5 & 0.31 & 0.60 & 0.27 & 0.46 \\
\hline $\begin{array}{l}\text { Somatotrophine }(\mathrm{GH}) \text {, } \\
\mathrm{ng} / \mathrm{ml}\end{array}$ & 2.92 & 1.58 & 2.76 & 3.29 & 1.16 & 0.09 & 0.47 & 0.98 & 0.22 \\
\hline Insulin, $\mathrm{ng} / \mathrm{ml}$ & 0.99 & 0.80 & $0.54^{\star *}$ & $0.68^{*}$ & 0.13 & 0.33 & 0.84 & 0.15 & 0.35 \\
\hline Insulin/GH ratio & 0.50 & 2.99 & 0.76 & 2.88 & 2.25 & 0.55 & 0.33 & 0.77 & 0.46 \\
\hline
\end{tabular}

${ }^{\mathrm{a}, \mathrm{b}, \mathrm{c}}$ Different letters within the same row indicate significant differences between treatments T1, T2 and T3 (LSD, $\alpha=0.05) . \wedge: P<0.10,{ }^{*}: P<0.05,{ }^{* *}: P<0.01: P$-value of the Student's $t$ for paired observations in comparison with the control treatment. ${ }^{1}$ Effects: $\mathrm{T}=$ Treatment, $\mathrm{P}=$ Period, $\mathrm{S}=$ Square. ${ }^{2}$ Average. ${ }^{3}$ Least square means. ${ }^{4}$ Standard error of least squares means. ${ }^{5}$ Non-esterified fatty acids. 


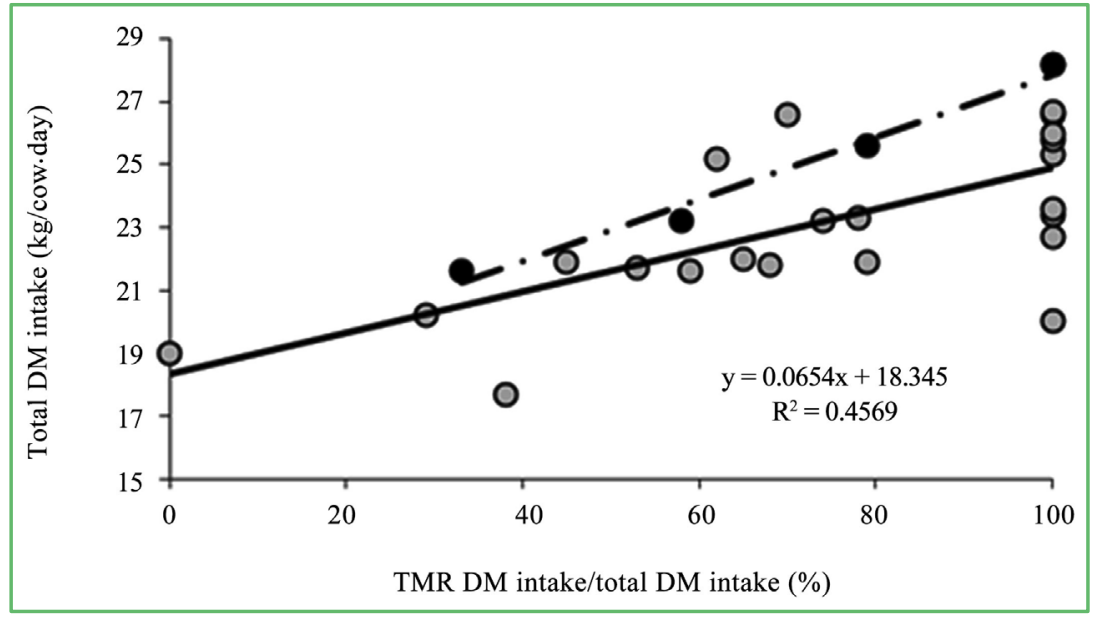

Figure 1. Intake of total dry matter in dairy cows fed different proportions of pasture and TMR. Solid line and gray points are data from [2] [3] [4] [6] [8] [9] [12] [18] and dotted line and black pointsare data from this experiment.

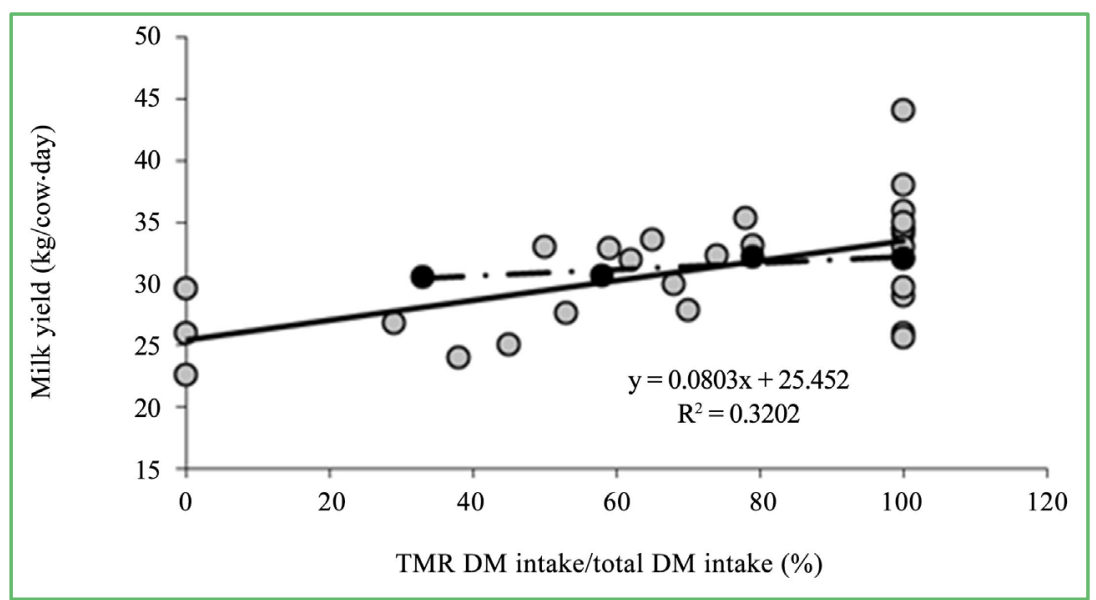

Figure 2. Production of milk from dairy cows fed different proportions of pasture and TMR. Solid line and gray points are data from [3] [4] [6] [8] [9] [10] [12] and dotted line and black points are data from this experiment.

TMR-100 and T1 was not apparently explained by a decrease of de novo synthesized fatty acids in the mammary gland or the appearance of some fatty acid inhibitors of mammary synthesis such as trans-10, cis-12 $\mathrm{C}_{18: 2}$ (Table 5). A dilution effect seems to be the most probably way to explain the lower milk fat concentration in TMR-100 and T1. Negative correlations between milk fat concentration with intake of TMR $(\mathrm{R}=-0.37, P<0.01)$ and energy $(\mathrm{R}=-0.33$, $P<0.03)$ were observed. These results, together with the lowest values of plasma NEFA in TMR-100 (Table 3) and the high BW, may reflect changes in the partitioning of energy towards lipogenesis in adipose tissue at the expense of mammary synthesis of milk fat. The higher plasma insulin concentrations in cows fed TMR-100 and T1 and the lack of increase in the GH/insulin ratio (Table 4) are factors predisposing to stimulate lipogenesis and to reduce the 
lipase activity in adipose tissue.

As already discussed, the actual amount of fiber provided by the corn silage in TMR-100 and T2 appeared to be adequate since the ruminal pH was higher than those observed in the other treatments [24]. This depressant trend of TMR intake on milk fat content was however not observed in other experiments [13] [15]. In mid-lactation cows fed TMR-100 and different TMR/pasture combinations, no differences in milk fat concentration were observed [5] [12].

As milk fat yield did not differ between treatments (Table 3 ) the lowest concentration of milk fat in TMR-100 and T1 treatments was apparently compensated by the higher milk output. No differences in milk fat yield were also observed in cows fed with varying proportions of TMR and pasture in both, autumn and spring experiments of [12]. Increased milk fat production in cows fed a 79:21 TMR/pasture diet $(1.39 \mathrm{~kg} /$ cow.day) compared to a diet with a greater pasture/TMR ratio $(63: 27)$ yielding $1.23 \mathrm{~kg}$ fat/cow.day with no differences to TMR-100 cows $(1.31 \mathrm{~kg} / \mathrm{cow} \cdot$ day) was reported in [15]. Since the quantity of milk produced was the same, the effect was explained by a higher concentration of milk fat in the 79:21 treatment [15]. Linear increases in milk fat output were reported when the proportion of TMR in the diet increased from $25 \%$ to $100 \%$ replacing an oat pasture [13].

In the present trial, milk protein concentration showed an erratic behavior (Table 3 ) resulting maximum in TMR-100 and T2 $(33.7 \mathrm{~g} / \mathrm{kg})$ but only higher $(P$ $<0.05)$ when compared to $\mathrm{T} 1(33.2 \mathrm{~g} / \mathrm{kg})$. The lowest protein concentration was observed in T3 $(32.9 \mathrm{~g} / \mathrm{kg})$ that in turn resulted only different from T2 $(33.7 \mathrm{~g} / \mathrm{kg})$. These results are not in keeping with experiments of [12] [13] [15] where no changes in milk protein concentration were detected. In the present trial, milk protein content was negatively correlated $(\mathrm{r}=-0.41, P<0.01)$ with circulating levels of plasma NEFA which in turn increased with the higher proportion of pasture in the PMR diets.

Milk protein yield resulted similar among the PMR treatments (Table 3). When compared to yield observed in TMR-100 (1.07 (kg/cow.day)), a lower $(P<$ $0.05)$ protein yield was detected in $\mathrm{T} 2$ (1.03) and in T3 (1.00) according to findings of [4] and [7]. The experiment of [13] showed linear increases in milk protein secretion as the proportion of the TMR increased in the total diet. Similar results were reported by [12] in spring pastures with maximal protein production in TMR-100 (1.04 kg/cow.day) and lower $(0.93 \mathrm{~kg} / \mathrm{cow} \cdot$ day $)$ in the PMR diets. In turn, milk protein yield was unaffected in [15].

Milk lactose content did not differ between PMR treatments (Table 3 but when compared to TMR-100 $(48.9 \mathrm{~g} / \mathrm{kg})$ lower $(P<0.05)$ values were detected in T2 $(47.0 \mathrm{~g} / \mathrm{kg})$ and T3 $(47.4 \mathrm{~g} / \mathrm{kg})$. Milk production and lactose concentration were positively correlated $(\mathrm{R}=0.38, P<0.01)$. A linear decrease in lactose with increased pasture in the PMR diets was reported by [13].

Milk production efficiency ( $\mathrm{kg}$ milk/kg DM intake) resulted higher in T3 $(1.42 \mathrm{~kg})$ compared to T1 $(1.25 \mathrm{~kg})$. A higher production efficiency was observed 
in treatments that included pasture compared to TMR-100 (1.13 kg). Thisresult may be partially explained by the higher total DM intake in TMR-100 and the apparently higher mobilization of endogenous energy (NEFA) to sustain milk production in the PMR treatments. A similar pattern of response was reported in [12].

\subsection{Plasma Metabolite and Hormone Concentrations}

A lower plasma urea concentration $(33.8 \mathrm{mg} / \mathrm{dl})$ was observed in TMR-100 with no significant differences between the PMR diets (Table 4). Using a similar oat pasture, lower uremia levels were also reported by [13] for the TMR-100 and TMR-75 diets compared to TMR-50 and TMR-15 treatments. Despite the higher CP intake (4.9 kg/cow.day) in TMR-100, lower plasma urea concentration were observed (Table 4). The high content of degradable protein of pasture [12] and/or a better energy/protein synchronization in the rumen of cows fed the TMR-100 diet might explain this apparent contradiction. In fact, in the companion digestion experiment by [24] the higher participation of oat pasture increased the ruminal $\mathrm{N}_{\mathrm{H} 3-\mathrm{N}}$ concentration and plasma urea levels in fistulated cows parameters that were positively correlated $(\mathrm{R}=0.68, P<0.05)$.

The lack of changes in uremia levels from T1 to T3 (Table 4) could be explained by a lower $\mathrm{N}_{-\mathrm{NH} 3}$ absorption due to the lower ruminal $\mathrm{pH}$ values observed [24]. A better efficiency of $\mathrm{N}_{-\mathrm{NH} 3}$ utilization and some enhanced ruminal synchrony when the pasture was combined with TMR can not be excluded. Plasma urea values in PMR's were slightly higher than in TMR-100 (Table 4). Differences between trials comparing urea concentrations in plasma and milk from cows consuming TMR-100 diets or PMR's can be explained by the quality of the pasture, content of degradable protein, amount of total DM and forage ingested, protein quality used to formulate the TMR's and the addition of urea to rations [7] [9] [13].

Plasma glucose concentrations did not differ between treatments including pasture (Table 4) as observed by [13]. Compared to TMR-100 (81.7 mg/dl) cows from T2 (42\% of pasture) showed higher plasma glucose $(94.4 \mathrm{mg} / \mathrm{dl})$. This was an unexpected result considering the high differences in total non structural carbohydrate content between the TMR (318 g/kg DM) and the pasture $(148 \mathrm{~g} / \mathrm{kg}$ DM). In [12] plasma glucose showed a mean value of $61.5 \mathrm{mg} / \mathrm{dl}$ in TMR-100 decreasing linearly with increased pasture intake. In the present experiment the higher concentration of glucose observed in T2 was consistent with the lower circulating plasma levels of insulin (Table 4$)(\mathrm{r}=-0.36, P<0.03)$.

A negative effect of increased pasture intake on the energy balance of high yielding dairy cows coupled to losses of BW and BCS is frequently reported [2] [4]-[9]. Cows fed TMR-100 diets either maintained their BW and BCS [4] [7] or showed improvements in these parameters [6] while cows of high genetic merit consuming pasture often mobilize body reserves with a significant loss in BCS [4] [6]. In our experiment, plasma NEFA gradually increased (Table 4) as the 
proportion of pasture was enhanced according to the estimated decrease in energy intake (Table 2). These results are consistent with the greater BW loss found in cows fed the highest proportions of pasture in the diet $(\mathrm{r}=-0.62, P<$ 0.01) suggesting that part of the produced milk could be sustained by endogenous energy mobilization. Similar results on the BW change of cows and circulating NEFA levels were reported in a similar trial by [13]. In the present experiment, the higher plasma insulin levels were found in those treatments where energy intake resulted greater (TMR-100 and T2) an effect that was not observed in [13]. Plasma insulin is positively correlated with periods of active food consumption and level of energy intake. Concentration of somatomedins (IGF-1) remained unaffected although it is a sensitive parameter to situations where the absolute or relative availability of nutrients is restricted. GH levels and the $\mathrm{GH} /$ insulin ratio were highly variable and not affected by treatments (Table 4). In the experiment of [13], as the oat-pasture intake was increased and theTMR decreased, weight losses and circulating GH values were enhanced but insulin levels remained unchanged. In our experiment, plasma GH and milk fat concentration ( $\mathrm{r}=0.64, P<0.01)$, IGF-1 and milk protein $(\mathrm{r}=0.40, P<0.02)$ and GH and IGF-1 $(\mathrm{r}=0.36, P<0.04)$ were correlated.

\subsection{Milk Fatty Acid Profile}

With the maximum pasture contribution in $\mathrm{T} 3$ a decrease in milk concentration (g/100g) of $\mathrm{C}_{12: 0}$ (3.68) was observed compared to $\mathrm{T} 1$ (4.0) and $\mathrm{T} 2$ (4.02) but not to T0 (3.86) (Table 5). Milk concentration of the atherogenic $\mathrm{C}_{1: 0}$ and $\mathrm{C}_{16: 0} \mathrm{FA}$ [26] was not affected. No differences in the concentration of short chain $F A\left(C_{6: 0}\right.$ to $\mathrm{C}_{12: 0}$ ) were detected when grazing was combined with increasing amounts of TMR [15]. The absence of effects of higher pasture intake on milk content of $\mathrm{C}_{\text {16:0 }}$ (Table 5) was not observed by [15] who reported a lower concentration of this FA in milk from grazing cows compared to those fed a TMR diet.

Increasing pasture intake did not significantly affect the concentration of the pro-atherogenic or unsaturated FA of milk which would explain the absence of effect on the atherogenicity index (Table 5 ). This parameter showed a relatively high average value (2.43) located in the range of $2.52-2.69$ reported in [13] for cows fed four different combinations of TMR and pasture. These authors [13] did not also observed differences in the total concentration of unsaturated FA as pasture intake increased.

Stearic $\left(\mathrm{C}_{18: 0}\right)$ acid content in milk was not affected but that of oleic acid (cis-9 $\mathrm{C}_{18: 1}$ ) was slightly decreased in $\mathrm{T} 1$ and $\mathrm{T} 2$ compared to $\mathrm{T} 0$ (Table 5). This result, and the observed lower desaturase activity index in T2 compared to T0 (Table 5) suggest a reduction in the delta-9 desaturase activity. A decrease in milk oleic acid content when pasture replaced TMR was not detected in [15] whereas in the experiment by [13] the maximum concentration of this FA was observed in the $75 \%$ pasture and $25 \%$ TMR diet. 
Table 5. Milk fatty acid profile from dairy cows fed a completely mixed ration (TMR-100) or combinations of TMR and pasture at 79:21 (T1), 58:42 (T2) and 33:67 (T3).

\begin{tabular}{|c|c|c|c|c|c|c|c|c|c|}
\hline \multirow{3}{*}{$(\mathrm{g} / 100 \mathrm{~g} \mathrm{FA})$} & \multirow{3}{*}{$\mathrm{TO}^{2}$} & \multicolumn{3}{|c|}{ Treatments } & \multirow{3}{*}{$\mathrm{SEM}^{4}$} & \multirow{3}{*}{$\mathrm{T}$} & \multicolumn{2}{|c|}{${ }^{1}$ Effects } & \multirow{3}{*}{$\mathrm{P}^{\star} \mathrm{T}$} \\
\hline & & \multicolumn{3}{|c|}{ Latin square ${ }^{3}$} & & & \multirow{2}{*}{$S$} & \multirow{2}{*}{$\mathrm{P}$} & \\
\hline & & $\mathrm{T}-1$ & $\mathrm{~T}-2$ & $\mathrm{~T}-3$ & & & & & \\
\hline $\mathrm{C}_{4: 0}$ & 1.92 & 2.14 & $2.13^{\wedge}$ & $2.20^{\wedge}$ & 0.073 & 0.75 & 0.43 & 0.00 & 0.04 \\
\hline$C_{6: 0}$ & 1.70 & 1.81 & $1.84^{\wedge}$ & 1.77 & 0.04 & 0.38 & 0.17 & 0.01 & 0.59 \\
\hline $\mathrm{C}_{8: 0}$ & 1.19 & $1.28^{\mathrm{a}}$ & $1.31^{\mathrm{a} \wedge}$ & $1.19^{\mathrm{b}}$ & 0.04 & 0.02 & 0.26 & 0.11 & 0.75 \\
\hline $\mathrm{C}_{10: 0}$ & 3.07 & $3.27^{\mathrm{a}}$ & $3.32^{\mathrm{a}}$ & $3.00^{\mathrm{b}}$ & 0.16 & 0.01 & 0.47 & 0.12 & 0.35 \\
\hline $\mathrm{C}_{10: 1}$ & 0.29 & $0.33^{\wedge}$ & $0.34^{*}$ & $0.33^{\wedge}$ & 0.02 & 0.67 & 0.71 & 0.24 & 0.26 \\
\hline $\mathrm{C}_{12: 0}$ & 3.87 & $4.00^{\mathrm{a}}$ & $4.02^{\mathrm{a}}$ & $3.68^{\mathrm{b}}$ & 0.23 & 0.04 & 0.61 & 0.01 & 0.37 \\
\hline $\mathrm{C}_{12: 1}$ & 0.08 & $0.093^{\mathrm{b} * *}$ & $0.102^{\mathrm{a} \star *}$ & $0.107^{a \star *}$ & 0.00 & 0.01 & 0.62 & 0.01 & 0.13 \\
\hline $\mathrm{C}_{14: 0}$ & 11.61 & $12.00^{\wedge}$ & $12.14^{* *}$ & 11.96 & 0.33 & 0.74 & 0.84 & 0.36 & 0.10 \\
\hline $\mathrm{C}_{14: 1}$ & 0.94 & 1.02 & 1.11 & 1.02 & 0.14 & 0.75 & 0.69 & 0.73 & 0.39 \\
\hline $\mathrm{C}_{15: 0}$ & 1.56 & $1.29^{*}$ & $1.22^{\star *}$ & $1.28^{\star *}$ & 0.07 & 0.40 & 0.68 & 0.01 & 0.22 \\
\hline Iso- $\mathrm{C}_{15: 0}$ & 0.42 & 0.37 & 0.29 & 0.51 & 0.08 & 0.22 & 0.49 & 0.51 & 0.36 \\
\hline $\mathrm{C}_{15: 1}$ & 0.21 & $0.224^{\mathrm{b} \wedge}$ & $0.253^{\mathrm{a} * *}$ & $0.261^{a * *}$ & 0.01 & $<0.01$ & 0.57 & 0.01 & 0.27 \\
\hline $\mathrm{C}_{16: 0}$ & 28.27 & $29.98^{\wedge}$ & 29.85 & 29.33 & 1.27 & 0.71 & 0.61 & 0.67 & 0.45 \\
\hline $\mathrm{C}_{16: 1}$ & 1.29 & 1.39 & 1.38 & 1.42 & 0.08 & 0.79 & 0.33 & 0.96 & 0.04 \\
\hline $\mathrm{C}_{17: 0}$ & 0.63 & $0.543^{\mathrm{a} \star *}$ & $0.510^{\mathrm{b} * *}$ & $0.506^{\mathrm{b} * *}$ & 0.02 & 0.06 & 0.28 & 0.33 & 0.70 \\
\hline $\mathrm{C}_{17: 1}$ & 0.22 & $0.20^{\mathrm{ab} \wedge}$ & $0.19^{b *}$ & $0.21^{\mathrm{a}}$ & 0.01 & 0.02 & 0.56 & 0.01 & 0.01 \\
\hline $\mathrm{C}_{18: 0}$ & 10.62 & $9.43^{\wedge}$ & 10.10 & 10.51 & 0.65 & 0.18 & 0.91 & 0.43 & 0.10 \\
\hline trans-9 $\mathrm{C}_{18: 1}$ (elaidic) & 0.49 & 0.36 & $0.26^{\star \star}$ & $0.28^{*}$ & 0.03 & 0.12 & 0.31 & 0.11 & 0.62 \\
\hline trans-10 $\mathrm{C}_{18: 1}$ & 1.23 & $0.783^{\mathrm{a}}$ & $0.552^{\mathrm{b} \wedge}$ & $0.382^{c *}$ & 0.05 & $<0.01$ & 0.28 & 0.05 & 0.34 \\
\hline $\begin{array}{c}\text { trans-11 } \mathrm{C}_{18: 1} \\
\text { (vaccenic. VA) }\end{array}$ & 1.45 & $1.84^{c * *}$ & $2.17^{\mathrm{b} *}$ & $2.77^{a * *}$ & 0.10 & $<0.01$ & 0.03 & 0.01 & 0.04 \\
\hline$c i s-9 \mathrm{C}_{18: 1}$ (oleic) & 21.69 & $20.06^{\star}$ & $20.19^{\star}$ & 21.16 & 1.00 & 0.20 & 0.49 & 0.82 & 0.46 \\
\hline cis-11 C18:1 & 1.07 & $0.91^{*}$ & $0.84^{\star *}$ & $0.84^{\star *}$ & 0.04 & 0.17 & 0.18 & 0.00 & 0.20 \\
\hline $\begin{array}{l}\text { cis-9, cis-12 } \mathrm{C}_{18: 2} \\
\quad \text { (linoleic) }\end{array}$ & 4.17 & $4.18^{\mathrm{a}}$ & $3.35^{\mathrm{b} * *}$ & $2.47^{c * *}$ & 0.17 & $<0.01$ & 0.38 & 0.00 & 0.22 \\
\hline $\mathrm{C}_{18: 3}$ (linolenic) & 0.32 & $0.51^{b * *}$ & $0.57^{b \star \star}$ & $0.67^{a \star \star}$ & 0.25 & $<0.01$ & 0.03 & 0.57 & 0.63 \\
\hline $\begin{array}{c}\text { cis-9, trans- } 11 \mathrm{C}_{18: 2} \\
\text { (CLA) }\end{array}$ & 1.07 & $1.23^{\mathrm{b} *}$ & $1.29^{\mathrm{b}}$ & $1.54^{\mathrm{a} \star \star}$ & 0.05 & $<0.01$ & 0.03 & 0.00 & 0.10 \\
\hline Total CLA & 1.12 & $1.29^{\mathrm{b} *}$ & $1.35^{\mathrm{b}}$ & $1.59^{a \star *}$ & 0.05 & $<0.01$ & 0.04 & $<0.01$ & 0.11 \\
\hline $\mathrm{C}_{20: 4}$ & 0.199 & $0.219^{\mathrm{a}}$ & $0.182^{\mathrm{b} *}$ & $0.166^{\mathrm{b} * *}$ & 0.01 & $<0.01$ & 0.65 & 0.58 & 0.82 \\
\hline $\mathrm{C}_{20: 5}(\mathrm{EPA})$ & 0.034 & $0.041^{\mathrm{b}}$ & $0.047^{b * *}$ & $0.059^{a \star *}$ & 0.00 & $<0.01$ & 0.67 & 0.40 & 0.31 \\
\hline $\mathrm{C}_{22: 6}(\mathrm{DHA})$ & 0.019 & 0.021 & 0.020 & 0.019 & 0.002 & 0.69 & 0.41 & 0.35 & 0.26 \\
\hline TOTAL FA & 99.66 & 99.58 & 99.63 & 99.70 & 0.04 & 0.23 & 0.64 & 0.48 & 0.86 \\
\hline De novo $\mathrm{FA}\left(\mathrm{C}_{4: 0}-\mathrm{C}_{15: 1}\right)$ & 26.84 & 27.83 & 28.07 & 27.30 & 0.72 & 0.31 & 0.58 & 0.33 & 0.19 \\
\hline
\end{tabular}




\section{Continued}

\begin{tabular}{cccccccccc}
\hline Preformed FA (>17:0) & 72.83 & 71.75 & $71.56^{\wedge}$ & 72.40 & 0.72 & 0.23 & 0.58 & 0.38 & 0.19 \\
CLA/VA ratio & 0.75 & $0.67^{\mathrm{a}}$ & $0.61^{\mathrm{ab} \star \star}$ & $0.56^{\mathrm{b} * *}$ & 0.02 & 0.01 & 0.61 & 0.71 & 0.01 \\
Desaturase index $^{5}$ & 0.32 & 0.31 & $0.31^{\wedge}$ & 0.32 & 0.01 & 0.25 & 0.40 & 0.82 & 0.65 \\
Atherogenicity index & 2.29 & 2.48 & $2.55^{\wedge}$ & 2.43 & 0.13 & 0.49 & 0.34 & 0.46 & 0.31 \\
Saturated FA, SFA & 64.85 & 66.13 & $66.73^{\wedge}$ & 65.93 & 0.97 & 0.51 & 0.23 & 0.13 & 0.37 \\
Unsaturated, UFA & 34.82 & 33.46 & $32.90^{\wedge}$ & 33.76 & 0.95 & 0.45 & 0.22 & 0.12 & 0.37 \\
SFA/UFA & 1.89 & 2.00 & 2.06 & 1.97 & 0.087 & 0.34 & 0.23 & 0.12 & 0.39 \\
\hline
\end{tabular}

a,b,c, Within the same row means with different letters differs (LSD, $\alpha=0.05) . \wedge: P<0.10,{ }^{*}: P<0.05$, **: $P<$ $0.01, P$ value for the Student $\mathrm{t}$-Test for paired observationscompared to T0. ${ }^{2}$ Effects of treatment (T); period (P) and square (S). ${ }^{3}$ Leasts square means. ${ }^{4}$ Estándar error of the mean. ${ }^{5}$ Desaturase Index: ([ $\Sigma \Delta 9$ Dproducts $] /[\Sigma \Delta 9 \mathrm{D}$ products + Susbstrates $])$. Substrates: $\mathrm{C}_{14: 0}+\mathrm{C}_{15: 0}+\mathrm{C}_{16: 0}+\mathrm{C}_{17: 0}+\mathrm{C}_{18: 0}+$ trans-11 $\mathrm{C}_{18: 1} \cdot{ }^{6}$ Atherogenicity index: $\left(\mathrm{C}_{12}+4{ }^{*} \mathrm{C}_{14}+\mathrm{C}_{16}\right) /($ UFA $)$. UFA: cis-9 $\mathrm{C}_{14: 1}, \mathrm{C} 16: 1$, cis- $9 \mathrm{C}_{18: 1}$, cis-11 $\mathrm{C}_{18: 1}$, trans-11 $\mathrm{C}_{18: 1}, \mathrm{C}_{18: 3}, \mathrm{C}_{18: 2}, \mathrm{C}_{18: 2}$ cis-9 trans11 CLA. The detrimental FA trans-6-8, 9, $10 \mathrm{C}_{18: 1}$ were excluded.

In the present experiment, increased TMR intake enhanced milk concentration of unhealthy FA like the trans-9 (elaidic) and trans-10 $\mathrm{C}_{18: 1}$ with a maximum value of $1.23 \mathrm{~g} / 100 \mathrm{~g}$ FA for trans-10 $\mathrm{C}_{18: 1}$ in T0 which represented an increase of $57 \%, 123 \%$ and $222 \%$ compared to $\mathrm{T} 1, \mathrm{~T} 2$ and $\mathrm{T} 3$ respectively. These results were not observed in the experiment of [13] when the TMR contribution increased from $25 \%$ to $100 \%$ in the diet. This authors reported very low values for both elaidic $\left(0.06 \mathrm{~g} / 100 \mathrm{~g}\right.$ of AG) and trans-10 $\mathrm{C}_{18: 1}(0.24-0.09 \mathrm{~g} / 100)$.

Concentration of trans-10, cis-12 $\mathrm{C}_{18: 2}$ in milk was not detected (Table 5) a result that could be explained by a high conversion of this FA to trans- $10 \mathrm{C}_{18: 1}$ in the rumen and its subsequent transfer to milk fat. No differences in milk concentration of trans-10, cis- $12 \mathrm{C}_{18: 2}(0.22$ to $0.26 \mathrm{~g} / 100 \mathrm{~g})$ were detected when the proportion of TMR ranged between $100 \%$ and $59 \%$ of the PMR [12].

In our trial, the maximum concentration of cis-9, trans- $11 \mathrm{C}_{18: 2}$ (CLA) in the PMR treatments was observed in T3 (1.54 g/100 g of FA) and decreased as the animals consumed a lower amount of pasture (Table 5 ) as previously reported [15] [25] [27] [28] [29].

As expected, milk VA (trans-11 $\mathrm{C}_{18: 1}$ ) concentration increased with pasture intake from a minimum value in T0 $(1.45 \mathrm{~g} / 100 \mathrm{~g})$ to a maximum of $2.77 \mathrm{~g} / 100 \mathrm{~g}$ when the TMR: pasture ratio was 33:67 (91\% increase). In the experiment by [15], milk VA concentration in confined 100\% TMR diet $(2.26 \mathrm{~g} / 100 \mathrm{~g})$ ) was doubled when the animals had access to pasture grazing for 6 (4.22) or 12 (4.09) hours. In contrast, no increase in milk VA content was detected as the pasture/TMR ratio increased [13].

Milk concentration of cis-9, trans-11 CLA in T0 $(1.07 \mathrm{~g} / 100 \mathrm{~g})$ resulted high if compared to the value of $0.30 \mathrm{~g} / 100 \mathrm{~g}$ reported in [15] when cows were fed the $100 \%$ TMR diet. In our trial, milk CLA content gradually increased with the inclusion of pasture in the PMR reaching a maximum value of $1.54 \mathrm{~g} / 100 \mathrm{~g}$ in T3 (Table 5). In the experiment of [15] significant increases in milk CLA con- 
tent were also obtained when cows grazed for $6(0.42 \mathrm{~g} / 100 \mathrm{~g})$ and 12 hours (0.60 g/100 g AG). The results of [12] confirmed linear increases of cis-9, trans-11 CLA as the pasture/TMR ratio was increased although the values obtained $(0.38-0.52 \mathrm{~g} / 100)$ were low when compared to those of the present work (Table 5). Differences in the botanical composition of the pastures and/or in the degree of maturity at grazing could explain the differences. In the companion experiment of [13] lower values of cis-9, trans-11 CLA were observed for the $100 \%$ TMR (0.84 g/100 g) and 75\% TMR (0.72) diets compared to those obtained in 50\% TMR (1.11)) and 25\% TMR (1.23).

In this trial, the CLA/VA ratio (indicator of delta-9 desaturase activity) tended to increase as pasture increased in the PMR which could reflect a constant activity of the enzyme. The concentration of linoleic acid (cis-9, cis-12 $\mathrm{C}_{18: 2}$ ) in milk tended to increase with the increasing participation of TMR (Table 5) a result often reported [12] [13] [15]. Increases in milk linolenic $\left(\mathrm{C}_{18: 3 \mathrm{n}-3}\right)$ acid content (Table 5) with higher pasture intake is a frequently reported effect [12] [13] [15] explained by the richness of linolenic in high quality pastures [30]. Unlike that observed by [15] increasing pasture intake did not reduce the proportion of saturated FA neither increase the unsaturated FA content of milk. The absence of effect on unsaturated FA could be explained by a high ruminal biohydrogenation of the polyunsaturated FA leading to a high VA production.

Taken together, the results obtained did not show important changes in the healthy value of milk fat when pasture intake decreased and contribution of TMR was enhanced. However, the higher content of vaccenic, CLA and linolenic acids would indicate a lower cardiovascular risk associated with the consumption of milk fat produced in production systems based on pasture.

\section{Conclusion}

The results obtained showed that the intake of fresh forage in combination with TMR may be a suitable strategy to maintain milk production. The conditions by replacing pasture for TMR should be defined taking into account the depressing effect of pasture on total DM and energy intakes of cows when fresh forage is included in high proportion in PMR. This effect may amplify the negative energy balance in high yielding dairy cows in early lactation with increased losses of BW, body condition and circulating levels of non-esterified fatty acids. Some deficiencies in forage quality in addition to animal behavior could exacerbate these effects. The efficiency of feed to milk conversion may be higher to the extent that a greater intake of pasture may be achieved but the observed increase in plasma of non-esterified fatty acids and weight loss suggested a mobilization of endogenous energy to sustain milk production. Operating in the long-term this effect may affect the health and production of high genetic merit cows in early lactation. It will be worthwhile to evaluate the effect of replacement of pasture by TMR in continuous long term experiments in early lactation cows 
of high genetic merit in order to quantify actual and residual effects on milk yield as well as the shape of the lactation curve and changes in parameters associated with body lipid mobilization, reproductive hormones and efficiency of milk production. Milk fatty acid composition varied in a favorable sense to consumer's health as the proportion of pasture increased due to a greater presence of conjugated linoleic and linolenic acids maintaining a lower content of elaidic and trans-10 $\mathrm{C}_{18: 1}$ without effects over the milk atherogenicity index.

\section{Acknowledgements}

This work was supported by the National Institute of Agricultural Technology (INTA). This Institute is a decentralized state agency with operational and financial autarchy, under the Ministry of Agroindustry of the Argentine Republic. This publication is a part of the Magister Scientiae Thesis by Med. Vet G. A. Quilaguy to access to the academic degree of Master in Agricultural Sciences. Mar del Plata National University (Argentina).

\section{References}

[1] Descalzo, A.M., Rossetti, L., Páez, R., Grigioni, G., García, P.T., Costabel, L., Negri, L., Antonacci, L., Salado, E., Bretschneider, G., Gagliostro, G., Comerón, E. and Taverna, M.A. (2012) Differential Characteristics of Milk Produced in Grazing Systems and Their Impact on Dairy Products. In: Chaiyabutr, N., Ed., Milk Production-Advanced Genetic Traits, Cellular Mechanism, Animal Management and Health, InTech, Rijeka, 339-368. https://doi.org/10.5772/50760

[2] White, S.L., Sheffield, R.E., Washburn, S.P., King, L.D. and Green, J.T. (2001) Spatial and Time Distribution of Dairy Cattle Excreta in an Intensive Pasture System. Journal of Environmental Quality, 30, 2180-2187. https://doi.org/10.2134/jeq2001.2180

[3] White, S.L., Benson, G.A., Washburn, S.P. and Green, J.T. (2002) Milk Production and Economic Measures in Confinement or Pasture Systems Using Seasonally Calved Holstein and Jersey Cows. Journal of Dairy Science, 85, 95-104. https://doi.org/10.3168/jds.S0022-0302(02)74057-5

[4] Kolver, E.S. and Muller, L.D. (1998) Performance and Nutrient Intake of High Producing Holstein Cows Consuming Pasture or a Total Mixed Ration. Journal of Dairy Science, 81, 1403-1411. https://doi.org/10.3168/jds.S0022-0302(98)75704-2

[5] Soriano, F.D., Polan, C.E. and Miller, C.N. (2001) Supplementing Pasture to Lactating Holsteins Fed a Total Mixed Ration. Journal of Dairy Science, 84, 2460-2468. https://doi.org/10.3168/jds.S0022-0302(01)74696-6

[6] Tucker, W.B., Rude, B.J. and Wittayakun, S. (2001) Case Study: Performance and Economics of Dairy Cows Fed a Corn Silage-Based Total Mixed Ration or Grazing Annual Ryegrass During Mid to Late Lactation. The Professional Animal Scientist, 17, 195-201. https://doi.org/10.15232/S1080-7446(15)31622-3

[7] Bargo, F., Muller, L.D., Delahoy, J.E. and Cassidy, T.W. (2002) Performance of High Producing Dairy Cows with Three Different Feeding Systems Combining Pasture and Total Mixed Rations. Journal of Dairy Science, 85, 2948-2963. https://doi.org/10.3168/jds.S0022-0302(02)74381-6

[8] Washburn, S.P., White, S.L., Green, J.T. and Benson, G.A. (2002) Reproduction, 
Mastitis, and Body Condition of Seasonally Calved Holstein and Jersey Cows in Confinement or Pasture Systems. Journal of Dairy Science, 85, 105-111. https://doi.org/10.3168/jds.S0022-0302(02)74058-7

[9] Fontaneli, R.S., Sollenberger, L.E., Littell, R.C. and Staples, C.R. (2005) Performance of Lactating Dairy Cows Managed on Pasture-Based or in Freestall Barn-Feeding Systems. Journal of Dairy Science, 88, 1264-1276. https://doi.org/10.3168/jds.S0022-0302(05)72793-4

[10] Vibart, R. (2006) Performance of Lactating Dairy Cows Fed Varying Levels of Total Mixed Ration and Pasture. Ph.D. Thesis, Graduate Faculty of North Carolina State University, Animal Science and Poultry Science, Raleigh.

[11] Dillon, P., Hennessy, T., Shalloo, L., Thorne, F. and Horan, B. (2008) Future Outlook for the Irish Dairy Industry: A Study of International Competitiveness, Influence of International Trade Reform and Requirement for Change: Review. International Journal of Dairy Technology, 61, 16-29. https://doi.org/10.1111/j.1471-0307.2008.00374.x

[12] Vibart, R.E., Fellner, V., Burns, J.C., Huntington, G.B. and Green, J.T. (2008) Performance of Lactating Dairy Cows Fed Varying Levels of Total Mixed Ration and Pasture. Journal of Dairy Research, 75, 471-480. https://doi.org/10.1017/S0022029908003361

[13] Salado, E.E., Bretschneider, G., Cuatrin, A., Descalzo, A.M. and Gagliostro, G.A. (2018) Productive Response of Dairy Cows Fed with Different Levels of Totally Mixed Ration and Pasture. Agricultural Sciences, 9, 824-851. https://doi.org/10.4236/as.2018.97058

[14] Kay, J.K., Roche, J.R., Kolver, E.S., Thomson, N.A. and Baumgard, L.H. (2005) A Comparision between Feeding Systems (Pasture and TMR) and the Effect of Vitamin E Supplementation on Plasma and Fatty Acid Profiles in Dairy Cows. Journal of Dairy Research, 72, 322-332. https://doi.org/10.1017/S0022029905000944

[15] Morales-Almaráz, E., Soldado, A., González, A., Martínez-Fernández, A., Domínguez-Vara, I., de la Roza-Delgado, B. and Vicente, F. (2010) Improving the Fatty Acid Profile of Dairy Cow Milk by Combining Grazing with Feeding of Total Mixed Ration. Journal of Dairy Research, 77, 225-230. https://doi.org/10.1017/S002202991000004X

[16] Kolver, E.S., Roche, J.R., De Veth, M.J., Thorne, P.L. and Napper, A.R. (2002) Total Mixed Rations versus Pasture Diets: Evidence for a Genotype x Diet Interaction in Dairy Cow Performance. Proceedings New Zealand Society of Animal Production, 62, 246-251.

[17] Fajardo, M., Mattiauda, D.A., Motta, G., Genro, T.C., Meikle, A., Carriquiry, M. and Chilibroste, P. (2015) Use the Mixed Rations with Different Access Time to Pastureland on Productive Responses of Early Lactation Holstein Cows. Livestock Science, 181, 51-57. https://doi.org/10.1016/j.livsci.2015.09.023

[18] Gagliostro, G.A., Garciarena, D.A., Rodriguez, M.A. and Antonacci, L.E. (2017) Feeding Polyunsaturated Supplements to Grazing Dairy Cows Improve the Healthy Value of Milk Fatty Acids. Agricultural Sciences, 8, 759-782. https://doi.org/10.4236/as.2017.88057

[19] ISO 9622 IDF 141 (2013) Milk and Liquid Milk Products-Guidelines for the Application of Mid-Infrared Spectrometry.

[20] Schroeder, G.F., Gagliostro, G.A., Becu-Villalobos, D. and Lacau-Mengido, I. (2002) Supplementation with Partially Hydrogenated Oil in Grazing Dairy Cows in Early 
Lactation. Journal of Dairy Science, 85, 580-594.

https://doi.org/10.3168/jds.S0022-0302(02)74112-X

[21] SAS Institute Inc. (2002-2010) SAS/STAT User's Guide. Cary.

[22] Schroeder, G.F., Elizalde, J.C. and Fay, J.P. (2000) Characterization of Corn Silage Produced in the Province of Buenos Aires. Revista Argentina de Producción Animal, 20, 161-170.

[23] Wales, W.J., Marett, L.C., Greenwood, J.S., Wright, M.M., Thornhill, J.B., Jacobs, J.L., Ho, C.K.M. and Auldist, M.J. (2013) A Use of Partial Mixed Rations in Pasture-Based Dairying in Temperate Regions of Australia. Animal Production Science, 53, 1167-1178. https://doi.org/10.1071/AN13207

[24] Montiel, M.D., Quilaguy-Ayure, G.A., Garciarena, D.A., Gagliostro, G.A., Cano, A.V., Antonacci, L.E. and Cangiano, C.A. (2010) Digestion and Rumen Environment of Dairy Cows Fed Different Levels of Completely Mixed Ration and Pasture. Revista Argentina de Producción Animal, 30, 464-465.

[25] Kelly, M.L., Kolver, E.S., Bauman, D.E., Van Amburgh, M.E. and Muller, L.D. (1998) Effect of Intake of Pasture on Concentrations of Conjugated Linoleic Acid in Milk of Lactating Cows. Journal of Dairy Science, 81, 1630-1636. https://doi.org/10.3168/jds.S0022-0302(98)75730-3

[26] Ulbritch, T.L. and Southgate, D.A.T. (1991) Coronary Heart Disease: Seven Dietary Factors. The Lancet, 338, 985-992. https://doi.org/10.1016/0140-6736(91)91846-M

[27] Jahreis, G., Frithsche, J. and Steinhart, H. (1997) Conjugated Linoleic Acid in Milk Fat: High Variation Depending on Production System. Nutrition Research, 17, 1479-1484. https://doi.org/10.1016/S0271-5317(97)00138-3

[28] Dhiman, T.R., Anand, G.R., Satter, L.D. and Pariza, M.W. (1999) Conjugated Linoleic Acid Content of Milk from Cows Fed Different Diets. Journal of Dairy Science, 82, 2146-2156. https://doi.org/10.3168/jds.S0022-0302(99)75458-5

[29] Loor, J.J., Soriano, F.D., Lin, X., Herbein, J.H. and Polan, C.E. (2003) Grazing Allowance after the Morning or Afternoon Milking for Lactating Dairy Cows Fed a Total Mixed Ration (TMR) Enhances trans 11-18:1 and cis 9, trans 11-18:2 (Rumenic Acid) in Milk Fat to Different Extents. Animal Feed Science and Technology, 109, 105-119. https://doi.org/10.1016/S0377-8401(03)00175-5

[30] Elgersma, A. and Wever, A.C. (2005) Grazing Fresh Grass at a High Herbage Allowance Results in Milk with a Higher CLA Concentration than a Maize Silage Diet. 26 th World Congress and Exhibition of the International Society for Fat Research, Prague, 61. 